\title{
EDUKASI PENGELOLAAN SAMPAH PADA ANAK DENGAN POLA PEMBERDAYAAN PARA ORANG TUA DI MASA PANDEMI COVID-19
}

\author{
Zaenafi Ariani \\ Prodi Ekonomi Syariah, Universitas Muhammadiyah Mataram \\ efisholiha@gmail.com
}

\section{INFO ARTIKEL}

\section{Riwayat Artikel:}

Diterima: 03-02-2021

Disetujui: 30-04-2021

\section{Kata Kunci:}

Edukasi,

Pengolahan Sampah,

Pemberdayaan Anak-anak, Pemberdayaan Orang Tua.

\section{Key Word}

\section{Education,}

Garbage treatment, Empowerment of Childre, Empowerment of Parents.

\section{A. LATAR BELAKANG}

Masalah lingkungan merupakan issue global yang berdampak terhadap banyak aspek kehidupan. Namun pemahaman tentang lingkungan dan khususnya limbah, nampaknya masih dalam tahap gaya hidup dan belum merupakan pola berpikir bagi masyarakat pada umumnya. Sampah adalah salah satu jenis limbah yang mau tidak mau dan sadar tidak sadar merupakan bagian dari kehidupan kita. Dimanapun kita bergerak maka akan meninggalkan bekas yang disebut limbah termasuk sampah. Masalah lingkungan selain merupakan issue global yang berdampak terhadap banyak aspek kehidupan, juga merupakan permasalahan yang kerap terjadi di perkotaan maupun di pedesaan. Permasalahan sampah ini dapat kita selesaikan dari aspek lingkungan yang paling bawah yaitu di tingkat desa. 
Desa adalah harapan kemajuan sebuah bangsa Paradigma selama ini yang menganggap desa adalah masyarakat yang tertinggal, dan untuk sukses haruslah merantau ke kota besar. Paradigma tersebut harus segera ditinggalkan. Oleh karena itu, membangun sebuah desa adalah harga mati yang harus segera direalisasikan. Sampah adalah limbah padat maupun cair yang berasal dari sisa-sisa yang tidak termanfaatkan oleh manusia baik perkotaan maupun perdesaan yang makin konsumtif. Salah satu cara mengubah perilaku masyarakat agar tidak membuang sampah kesungai, selokan, membakar dengan cara menerapkan strategi 3 Ryaitureuse, reduce, dan recycle. Namun konsep ini tidak berjalan dengan baik karena masyarakat berfikir bahwa sampah itu adalah barang yang tidak berharga, tidak bermanfaat, dan tidak mempunyai nilai ekonomi. Lalu jalan keluar yang paling mudah dan gampang adalah membuangnya diselokan tanpa memikirkan dampak yang akan terjadi. Sampai saat ini, pengelolaan sampah adalah masalah yang belum bisa ditanggulangi didesa Perampuan(Mappanyompa, 2019).

Permasalahan sampah semakin meningkat seiring bertambahnya penduduk dan adanya perubahan gaya hidup dan pola konsumsi masyarakat yang menghendaki segala sesuatu yang bersifat simple dan praktis. Persoalan sampah yang tidak bisa teratasi akan mengancam kehidupan manusia dan lingkungan secara umum. Disamping mempunyai dampak buruk, sampah sebenarnya mempunyai potensi yang cukup besar sebagai asset usaha apabila dapat dikelola dengan baik. Hanya saja masyarakat didesa Perampuan belum sadar bagaimana cara mengolah sampah dan mengolahnya menjadi sumber daya yang mampu menambah sumber pendapatan bagi keluarga.

Beberapa penelitian yang terkait dengan pengelolaan sampah, antara lain adalah :

1. Putri Nilam Sari (2016), dengan judul Analisis Pengelolaan Sampah Padat Di Kecamatan Banuhampu Kabupaten Agam dalam Jurnal Kesehatan Masyarakat Andalas Vol 10 No. 2, yang menyimpulkan bahwa Sistem pengelolaan sampah di Keca matan Banuhampu belum berjalan dengan baik dibuktikan dengan belum adanya perenca naan khusus dalam pengelolaan sampah kare na tidak adanya tempat pengelolaan sampah. Untuk pelaksanaan pengelolaan sampah, di daerah pinggir kota telah terdapat masyarakat yang bekerjasama dengan Kota Bukittinggi dan di daerah pedesaan telah ada masyarakatyang mengelola sampah dengan membuat kompos, tetapi sebagian besar sampah masih dibuang sembarangan.

2. M. Hariansyah dan Achyar Eldine (2016), yang berjudul Pengembangan Teknologi Tepat Guna Dalam Pengelolaan Sampah Plastik yang termuat dalam Jurnal Ilmiah akuntansi dan Keuangan Universitas Ibn Khaldun yang berkesimpulan bahwa untuk meningkatkan usaha agar bernilai ekonomis maka pembelian dan penjualan sampah tidak hanya terbatas pada bekas botol minuan aqua atau sejenisnya, tetapi lebih dikembangkan kepada pembelian dan penjualan sampah anorganik lainnya. Beberapa pembenahan yang masih dianggap lemah adalah system menejemen pengelolaan sampah, serta mengatur system keuangan.

3. Edy Suyanto dkk (2015), dengan Judul Model Kebijakan Pengelolaan Sampah Berbasis Partisipasi "Green Community" Mendukung Kota Hijau dengan salah satu temuan dalam penelitiannya menunjukkan bahwa model alternatif kebijakan Pemda dalam pengelolaan sampah mendukung kota hijau adalah memprioritaskan partisipasi green community, dengan berbagai dukungan serta konsistensi dalam pelaksanaan aturan. Untuk pemangku kepentingan yang paling berpengaruh dalam kebijakan adalah masyarakat, sedangkan aspek alternatif yang menjadi bahan pertimbangan utama dalam kebijakan adalah aspek kota bersih dari sampah. Untuk mewujudkan kebijakan tersebut, maka perlu dilakukan secara terpadu antar berbagai stakeholder terkait.

4. Apri Utami Parta Santi dkk (2020), dengan judul Penelitian pengaruh pengetahuan pengelolaan sampah terhadap perilaku pemilahan sampah pada mahasiswa PGSD FIP UMJ, yang diterbitkan pada Jurnal Jurnal Elementaria Edukasia Volume 3 No 2 Tahun 2020, kesimpulan Yaitu tidak ada pengaruh signifikan antara pengetahuan sampah dengan kebiasaan pemilah sampah. Namun Penelitian ini dilatarbelakangi dari tingkat pengetahuan dan kesadaran untuk mengolah sampah yang tergolong rendah.

5. Nisa Larasati dkk (2020), dalam penelitian Yang berjudul, Analisis Sistem Pengelolaan Sampah Organik di Universitas Indonesia (Studi Kasus Efektivitas Unit Pengolahan Sampah UI Depok) dengan hasil penelitian Sumber sampah 
yang dihasilkan oleh aktivitas di Universitas Indonesia berasal dari gedung, kantin, taman, dan laboratorium. Jenis sampah yang dihasilkan adalah organik berupa sisa makanan, daun, dan sampah taman lainnya; sampah anorgan- ik berupa botol, kertas, dan plastik; dan sampah Ba- han Berbahaya dan Beracun. Jumlah sampah organ- ik yang dihasilkan di 12 kantin fakultas pada tahun 2017 adalah sebesar $148.652 \mathrm{~kg}$ dengan jumlah sivi- tas mencapai 53.641 orang. Tingkat efektivitas UPS UI dalam mengolah sampah tersebut mencapai 99.35\%. Sistem pengelolaan sampah yang diberlakukan yaitu pemilahan dan pewadahan pada tingkat fakultas, pengangkutan, pengolahan, dan pem- rosesan akhir pada tingkat universitas. Perilaku pem- bakaran sampah masih dilakukan oleh salah satu fakultas di Universitas Indonesia.

6. Muchammad Zamzami Elamin dkk (2018), dalam penelitiannya yang berjudul Analisis Pengelolaan Sampah Pada Masyarakat Desa Disanah Kecamatan Sreseh Kabupaten Sampang dalam Jurnal yang diterbitkan oleh Jurnal Kesehatan Lingkungan, Vol.10 , No.4, Oktober 2018: 368-375 dengan kesimpulan bahwa Sistem pengelolaan sampah yang dimiliki Desa Disanah masih belum baik. Hal ini bisa ditinjau dari perilaku warga yang terbiasa membuang sampah tidak pada tempatnya/sembarangan yaitu seperti pada lahan kosong, tambak, selokan dan di sekitaran jalan. Selain itu, pemahaman akan pentingnya pengelolaan sampah juga kurang baik. Pengelolaan yang dilakukan hanya sebatas pembuangan yang tidak pada tempatnya dan pembakaran. Hal tersebut diakibatkan karena tidak adanya fasilitas sarana dan prasarana yang mendukung seperti tempat sampah di tiap rumah, tempat penampungan sementara (TPS) dan lain-lain. Masalah utama dalam hal pengelolaan sampah di Desa Disanah adalah lahan untuk pembangunan tempat penampungan sementara (TPS) serta akses menuju ke Desa yang masih dalam tahap pembangunan. Hal lain yang menunjang terjadinya pembuangan sampah tidak pada tempatnya juga dipengaruhi oleh tingkat kesadaran warga akan kebersihan lingkungan masih kurang baik.

7. Sulisa dkk, yang berjudul Pengelolaan Sampah Berbasis Masyarakat di Wilayah Pesisir (Studi Kelurahan Pulau Penyengat)Adapun kesimpulan yang diambil adalah Dalam aspek kelembagaan, tidak berjalannya Badan Pengelola Sampah dan belum adanya petugas yang ditunjukkan RT/RW selaku badan yang berwenang untuk membentuk lembaga yang bertanggungjawab terhadap pengelolaan sampah. Pengolahan belum menggunakan konsep 3R (Reduce, Reuse, Recycle) yang dikelola badan pengelola sampah maupun komunitas masyarakat yang mengelola sampah. Sudah berperannya lembaga pemerintah dalam pengelolaan sampah baik dari aspek pengurangan oleh Dinas Lingkungan Hidup Kota Tanjungpinang maupun penanganan sampah oleh Dinas Perumahan Rakyat, Kawasan Permukiman Kebersihan dan Pertamanan Kota Tanjungpinang. Namun belum adanya monitoring berkala yang dilakukan, sehingga masih terdapat kelalaian dalam pengelolaan sampah seperti, keterlambatan waktu petugas harian lepas dalam melaksanakan tugasnya.

8. Karlita Ayu Suntari (2018), dalam skripsinya yang berjudul Kajian Pengelolaan Sampah Berbasis Masyarakat Di Kawasan Perkotaan Ciwidey dengan kesimpulan bahwa ada beberapa arahan yang diperlukan dalam pengelolaan sampah berbasis masyarakat, meliputi: Arahan teknis operasional dengan kegiatan pengurangan dan penanganan sampah, Arahan kelembagaan dengan pembentukan tugas dan tanggung jawab stakeholder, Arahan peraturan dengan pembentukan insentif dan disisentif, Arahan partisipasi/peran serta masyarakat denganpengadaan dialog / forum / musyawarah, sosialisasi, dan pelatihan.

9. Anissa Christy Maharani , dalam skripsi yang berjudul ANALISIS Strategi Keberhasilan Pengelolaan Bank Sampah Menggunakan Metode Ahp (Analytical Hierarchy Process) Dan Swot (Strength, Weakness, Opportunity, Threat) Di Kota Surakarta dengan kesimpulan bahwa Rekomendasi strategi WO dalam pelaksanaan keberhasilan bank sampah yaitu: memberikan kegiatan sosialisasi, pelatihan dan pembinaan kepada masyarakat setiap minggu secara rutin, melakukan uji laboratorium mengenai kandungan zat serta bau yang terdapat pada pupuk kompos serta meningkatkan kerjasama antar stakeholders.

10. Ricky Febriyanto, dalam naskah proseding yang berjudul Analisis Sistem Pengelolaan Sampah Kota (Studi Kasus: Kota Serang) Kesimpulan dari tulisannya adalah Berdasarkan hasil analisis dan pembahasan yang telah disampaikan sebelumnya, maka dapat disimpulkan bahwa karakteristik timbulan sampah Kota Serang ditandai dengan pertumbuhan Jumlah Timbulan Sampah (JTS), 
cenderung mengalami peningkatan mengikuti pertumbuhan penduduk dan tingkat kepadatan penduduk. Diperkirakan pada tahun 2014, nilai JTS di Kota Serang adalah sebesar 78.409.628,50 kg dengan nilai TSK sebesar 0,35 $\mathrm{kg} /$ jiwa/hari. Sistem pengelolaan sampah Kota Serang yang dinilai berdasarkan penilaian indikator cakupan pelayanan persampahan dan Jumlah Sampah TPA dari tahun 2008-2030, yaitu sebesar $46,37 \%$ per tahun dan $1.891 .617,19 \mathrm{~m}^{3}$, menunjukan bahwa sistem pengelolaan sampah Kota Serang tidak berkelanjutan.

11. Arie Herlambang dan Djoko Heru Martono (2008), yang berjudul Teknologi Pengolahan Sampah dan Air Limbah adapun kesimpulan yang diambil adalah Prinsip $3 \mathrm{R}$ (Reduce, Reuse, dan Recycle) merupakan prinsip yang sudah diakui keberhasilannya oleh negara-negara maju dalam mengelola limbahnya, prinsip tersebut dalam aplikasinya di Indonesia masih bersifat wacana. Dalam menerapkan prinsip 3R dalam sistem pengelolaan sampah, diperlukan dukungan teknologi yang memadai. Dukungan tersebut sangat diperlukan dalam upaya mencari metoda dan cara yang sesuai dengan kondisi negara kita; Dengan komposisi mayoritas (70 - $80 \%$ ) sampah dari perkotaan terdiri dari bahan organik yang dapat terurai secara alamiah dan 20 - $30 \%$ bahan non organik, maka proses komposting merupakan salah satu proses alternatif yang paling murah dengan hasil sampingan yang dapat dimanfaatkan kembali sebagai pupuk organic; Limbah cair yang terbuang keperairan alam terdiri sebagian besar (77-80\%) dari limbah cair domestik, oleh karena itu diprioritas dalam penanganannya. Teknologi pengolahannya banyak macam dan ragamnya, namun demikian dalam pemilkihan teknologi biaya investasi, operasi dan pemeliharaan menjadi pertimbangan utama, selain hasil air olahan yang ingin dicapai; Pencemaran yang terjadi di laut atau teluk atau pelabuhan tidak terlepas dari pencemaran yang terjadi di sungai-sungai yang bermuara ke laut, oleh karena itu penanganan pencemaran di laut tidak terlepas dari penanganan pencemaran air dan penanganan sampah yang ada di darat.

12. Fildza Mazaya Thirafi Romala, dkk. (2020), yang berjudul "Penerapan Konsep Eduwisata pada Pusat Pengolahan Sampah Putri Cempo" adapun kesimpulan yang diambi adalah proses pengolahan sampah menjadi produk-produk layak guna yang ada di Surakarta. Pengolahan tersebut perlu dilakukan seiring meningkatnya produksi sampah yang berpotensi menimbulkan pencemaran air, udara dan juga bencana. Pusat pengolahan sampah memproses sampah dalam jumlah besar sehingga efektif untuk mengurangi kerusakan lingkungan akibat sampah. Untuk memberi dampak positif yang maksimal bagi masyarakat, dimanfaatkan pula sebagai sarana wisata edukasi yang memperkenalkan dan mengajak masyarakat turut mengolah sampah secara mandiri. Eduwisata pengolahan sampah menyediakan fasilitas edukasi berupa penyampaian pengetahuan tentang pengolahan sampah kepada pengunjung, serta fasilitas rekreasi wisata yang nyaman dan aman bagi pengunjung. Metode perencanaan dan perancangan dilakukan dengan pengumpulan data yang kemudian dianalisis berdasarkan standar perancangan arsitektur dan pengolahan sampah. Analisis tersebut kemudian dirumuskan menjadi konsep perencanaan dan perancangan untuk memecahkan permasalahan desain. Hasil penerapan konsep eduwisata pada Pusat Pengolahan Sampah Putri Cempo sebagai Eduwisata di Surakarta meliputi penataan ruang dan tapak, tampilan dan struktur bangunan, serta utilitas lingkungan.

13. Maulida Imania Utami, dkk. (2020), yang berjudul "Proses Pengolahan Sampah Plastik di UD Nialdho Plastik Kota Madium" adapun kesimpulan yang diambil adalah proses pengolahan sampah plastik di Unit Dagang Nialdho Plastik terdapat empat tahap yaitu: 1) pengepulan, 2) penyortiran, 3) pengepakan, dan 4) pendistribusian. Setiap jenis plastik me miliki harga yang berbeda per kilogram berdasarkan karakteristik plastiknya

14. Rizki Aziz, dkk (2020), yan berjudul "Kajian Awal Pengolahan Sampah Kawasan Wisata Pantai Carocok Kota Painan" adapun kesimpulan yang dapat diambil adalah Pengolahan sampah yang dapat dilakukan berupa pengomposan untuk sampah makanan dan halaman, dan didaur ulang untuk sampah plastik, kertas, kaca, dan logam, sedangkan sisanya dapat ditransportasikan ke Tempat Pemrosesan Akhir sampah. Pengolahan sampah dapat dilakukan di Tempat Pengolahan Sampah berbasis reduce, reuse, recycle (TPS 3R).

15. Dyah Rini Indriyanti, dkk (2015), yang berjudul "Pengolahan Limbah Organik Sampah Pasar Menjadi Kompos" adapun kesimpulan yang dapat diambil adalah kegiatan proses pengabdian di masyarakat dapat melatih petugas KSM Pasar Sampangan Baru mengolah 
sampah organik menjadi kompos atau pupuk organik. Ada dua kelompok mitra yaitu: pertama kelompok para pedagang khususnya pedagang sayur mayur, setiap hari meraka menghasilkan sampah organik dan non organik. Mereka berjumlah kurang lebih 75 pedagang. Kelompok kedua adalah pengolah sampah organik, sebanyak tiga orang. Metode pengabdian masyarakat sebagai berikut: sosialisasi dan koordinasi pihak terkait, menyediakan rumah kompos, pengadaan alat \& bahan, pelatihan pembuatan pupuk kompos, pengolahan sampah organik secara rutin. Hasil yang diperoleh: KSM Pasar Sampangan Baru sudah mengolah sampah organik pasar menjadi pupuk kompos dan produk sudah dijual.

\section{B. METODE PENELITIAN}

\section{Jenis Penelitian}

Penelitian ini menggunakan metode destriktif kualitatif. Metode deskriftif kualitatif bertujuan untuk menggambarkan, meringkas berbagai kondisi, berbagai situasi atau berbagai fenomena realitas social masyarakat yang menjadi obyek penelitian, dan berupaya menarik realitas itu ke permukaan sebagai suatu ciri, karkter, sifat, model, tanda atau gambaran tentang kondisi, situasi, ataupun fenomena tertentu (Bungin, 2011:68).

\section{Instrumen Penelitian}

Instrumen penelitian dalam penelitian ini adalah peneliti itu sendiri. Peneliti adalah instrument kunci (key instrument). Penelitilah yang mengadakan sendiri pengamatan atau wawancara tak berstruktur dan hasil catatan. Hanya manusia sebagai instrument yang dapat memahami makna interaksi antar manusia, mengalami perasaaan dan nilai-nilai yang terkandung dalam ucapan dan perbuatan responden. Peneliti sebagai key instrument berfungsi untuk menetapkan focus penlitian, memilih informan sebagai sumber data, melakukan pengumpulan data, analisis data, menafsirkan data dan membuat kesimpulan atas semuanya (Sugiono, 2012:222).

\section{Informan Kunci}

Untuk memperoleh data yang akurat diperlukan informan kunci. Informan kunci adalah informan yang benar-benar menguasai situasi social yang diteliti. Informan kunci atau informan yang baik adalah informan yang baik adalah informan yang memiliki kriteria sebagai berikut:
Mereka yang mengusai atau memahamisesuatu melalui proses enkulturasi, sehingga sesuatu itu bukan sekedar diketahui, tetapi juga dihayatinya. Mereka yang masih sedang berkecimpung atau terlibat pada kegiatan yang tengah diteliti. Mereka yang mempunyai wwaktu yang memadai untuk dimintai keterangan. Mereka yang cenderung tidak menyampaikan informasi hasil "kemasannya" sendiri (Sugiono, 2012:221).

\section{Lokasi Dan Waktu Penlitian}

Penelitian ini dilakukan di Desa Perampuan Kecamatan Labuapi Kabupaten Lombok Barat yang dilakukan selama 6 Bulan.

\section{Prosedur Pengumpulan Data}

Dalam penelitian kualitatif, pengumpulan data dilakukan pada natural setting (kondisi alamiah), sumber data primer, dan teknik pegumpulan data lebih banyak pada observasi, wawancara mendalam dan dokumentasi (Sugiono, 2012:225).

\section{Prosedur Analisa Data}

Bongdan (dalam Sugiono:2013:88) menyatakan bahwa analisis data adalah proses mencari dan menyusun secara sistimatis data yang diperoleh dari hasil wawancara, catatan lapangan, dan bahan-bahan lainsehingga dapat mudah dipahami, dan temuannyadiinformasikan kepada orang lain. Menurut Nasution (dalam Sugiono, 2013:89) analisis data dalam penelitian kualitatif lebih difokuskan selama proses dilapangan bersamaan dengan pengumpulan data, dimana didalam kenyataannya, analisis data kulaitatif berlangsung selama proses pengumpulan data daripada setelah selesai pengumpulan data.

\section{Uji Keabsahan Data}

Dalam penelitian ini, dilakukan uji keabsahan data melalui uji kredibilitas (kepercayaan) data dengan teknis triangulasi. Menurut Wiersma (dalam Sugiono,2013:125), triangulasi dalam pengujian kredibilitas ini diartikan sebagai pengecekan data dari berbagai sumber dengan berbagai cara, dan berbagai waktu. Terdapat tiga jenistriangulasi, yaitu: triangulasi sumber, triangulasi teknik, dan triangulasi waktu.

\section{HASIL DAN PEMBAHASAN}

Bab ini membahas tentang deskripsi, analisa data dan pembahasan terkait edukasi pengelolaan sampah pada anak dengan pola pemberdayaan para 
orang tua pada masa pandemic covid 19. Adapun yang menjadi instrument pada penelitian ini adalah peneliti itu sendiri dimana peneliti sebagai pegiat Bank Sampah pada lokasi penelitian. Hal yang berbeda dari penelitian sebelumnya adalah jarang sekali ada penelitian yang membahas keterlibatan atau peran anak anak dalam penangannan masalah sampah, para orang tua terkadang abai dalam melibatkan bahkan mengarahkan anak anak dalam pengelolaan sampah. Sementra anak anak merupaka salah satu penyumbang yang signifikan dalm hal persampahan karena kebutuhan anak anak dalammengkonsumsi barang ataupun jasa tidak kalah dengan orang tua.

\section{Tahap observasi}

Pada tahap observasi ini, dilakukan oleh peneliti sendiri, untuk melihat menggali informasi langsung kondisi fisik, lapangan, data potensi wilayah mitra baik pada aspek fisik, sosial, ekonomi, maupun lingkungan. Selain hal tersebut, obeservasi juga bertujuan untuk mendapatkan data-data akurat yang dipergunakan dalam penyusunan dan pelaksanaan penelitian berupa karakteristik dan potensi yang ada di Dusun Perampuan kecematan Labuapi Kabupaten Lombok Barat. Berdasarkan hasil observasi kami bahwa pengetahuan anakanak terhadap pengelolaan sampah masih sangat kurang sehingga anak-anak tersebut membuang begitu saja sampah dari hasil jajanan sehari-hari padahal sampah itu ketika dikelola akan menjadi barang yang bernilai ekonomi. Begitu pula dengan para orang tua yang terkadang abai dalam mengarahkan anak nya untuk mengelola sampah yang mereka hasilkan, kalaupun para orang tua melakukan pemilahan sampah terkadang tidak melibatkan anak anak dalam melakukannya. Adapun Permasalahan yang dialami oleh anak-anak dan orangtua di Desa Perampuan Barat, bahwa mereka mengaku akan kekurangan sumber daya manusia untuk mengelolah atau untuk mendaur ulang sampah yang ada dirumah masing-masuing. Oleh karena itu, dari hasil penelitian ini akan menjadi acuan dalam melakukan sosialisasi pengenalan dan pemilahan sampah.

\section{Informan Kunci}

Untuk memperoleh data yang akurat diperlukan informan kunci. Informan kunci adalah informan yang benar-benar menguasai situasi social yang diteliti. Adapun informan kuncipada penelitian ini adalah Bapak Kepala Dusun Perampuan Barat Yaitu Bapak Sairi, beliau menginformasikan bahwa masih sangat kurangnya pemahaman masyarakat terkait dengan permasalahan sampah ini. Apalagi terkait dengan pelibatan anak anak sebagai pembelajaran bagi mereka itu belum ada, padahal di lingkungan dusun perampuan barat itu sendiri terdapat sekolah dari jenjang PAUD, TK, maupun SD yang sebenarnya bisa menerapkan pelibatan anak anak dalam mengelola sampah. Menurut beliau ini membuktikan bahwa peran para orang tua dalam mengarahkan atau mengedukasi anak anak dalam hal pengelolaan sampah masih sangat kurang.

\section{Analisa Data}

Peneliti melakukan analisis data dalam penelitian ini lebih difokuskan selama proses dilapangan bersamaan dengan pengumpulan data, dimana didalam kenyataannya, analisis data kulaitatif berlangsung selama proses pengumpulan data.

\section{TEMUAN}

Setiap orang tua telah mengajarkan pada anak mereka tentang bersikap baik kepada orang lain akan tetapi banyak yang gagal untuk menerapkan kebaikan kepada lingkungan sebagai faktor penting. Padahal, degradasi lingkungan terjadi dengan cepat, dimana pemanasan global meningkat secara perlahan tapi pasti. Sehingga sangat penting bagi kita untuk mengajarkan generasi masa depan sifat ramah lingkungan baik dalam hal pengelolaan sampah. Lingkungan tempat tinggal akan menjadi tempat yang tak tertahankan untuk ditempati jika lingkungan terus memburuk dengan pengelolaan sampah yang tidak tepat. Sangat penting untuk menanamkan pentingnya pengelolaan sampah yang mereka hasilkan sendiri pada anak-anak selain kebaikan lain pada umumnya, budaya dan kearifan.

\section{E. SIMPULAN DAN SARAN}

Permasalahan sampah semakin meningkat seiring bertambahnya penduduk dan adanya perubahan gaya hidup dan pola konsumsi masyarakat yang menghendaki segala sesuatu yang bersifat simple dan praktis. Persoalan sampah yang 
tidak bisa teratasi akan mengancam kehidupan manusia dan lingkungan secara umum. Disamping mempunyai dampak buruk, sampah sebenarnya mempunyai potensi yang cukup besar sebagai asset usaha apabila dapat dikelola dengan baik. Hanya saja masyarakat didesa Perampuan belum sadar bagaimana cara mengolah sampah dan mengolahnya menjadi sumber daya yang mampu menambah sumber pendapatan bagi keluarga.

Berdasarkan hasil observasi langsung ke lapangan tepatnya di rumah warga dusun Perampuan Barat, maka diperoleh informasi bahwa anak-ank warga setempat masih kurang mendapatkan edukasi tentang pengelolahan sampah yang disebabkan oleh para orang tua yang masih abai dan tidak melibatkan anak-anak mereka dengan masalah sampah itu sendiri. Untuk penelitian berikutnya peneliti menyarankan agar dilakukannya penelitian bagaimana pengelolaan sampah dengan pendekatan Sosial Marketing, sehingga dapat dilihat produk mana saja yang paling berperan penyumbang sampah dalam masyarakat.

\section{DAFTAR RUJUKAN}

Apri Utami Parta Santi. (2020). Pengaruh Pengetahuan Pengelolaan Sampah Terhadap Perilaku Pemilahan Sampah Pada Mahasiswa Pgsd Fip Umj. Jurnal Elementaria Edukasia Volume 3 No 2 Tahun 2020. 193-202.

Arie Herlambang dan Djoko Heru Martono. (2008). Teknologi Pengolahan Sampah dan Air Limbah. JAI Vol.4, No2, Tahun 2008.

Aziz Rizki, dkk.(2020). "Kajian Pengolahan Sampah Kawwasan Wisata Pantai Carocok Kota Painan". Jurnal Sains dan Teknologi Vol. 20 No. 1. (juni 2020).

Edi Suyanto (2015). Model Kebijakan Pengelolaan Sampah Berbasis Partisipasi "Green Community" Mendukung Kota Hijau. Jurnal Mimbar , Vol. 31, No. 1 (Juni, 2015): 143-152.

Fildza Mazaya Thirafi Romala (2020). Penerapan Konsep Eduwisata pada Pusat Pengolahan Sampah Putri Cempo. Vol 3 No 2 (Juli 2020) : 415-426.

Hariansyah (2016). Pengembangan Teknologi Tepat Guna Dalam Pengelolaan Sampah Plastik. Jurnal Ilmiah Akuntansi dan Keuangan. Universitas Ibnu Kaldun. Vol 11 No. 2 (2016).

Indriyanti Dyah Rini, dkk. (2015). Pengolahan Limbah Organik Sampah Pasar Menjadi Kompos. ABDIMAS Vol. 19 No. 1 (Juni 2015): 43-48
Karlita Ayu Suntari (2018). Skripsi. Kajian Pengelolaan Sampah Berbasis Masyarakat Di Kawasan Perkotaan Ciwidey. Program Studi Perencanaan Wilayah Dan Kota Fakultas Teknik. Universitas Pasundan Bandung. 2018.

Moleong, Lexy, J. (2014). Metodologi Penelitian Kualitatif. Cetakan ke-33, Bandung: Remaja Rosadakarya.

Muchammad Zamzami Elamin (2018). Analisis Pengelolaan Sampah Pada Masyarakat Desa Disanah Kecamatan Sreseh Kabupaten Sampang. Transparansi Jurnal Ilmiah Ilmu Administrasi.

Nisa Larasati dkk. (2020). Analisis Sistem Pengelolaan Sampah Organik di Universitas Indonesia (Studi Kasus Efektivitas Unit Pengolahan Sampah UI Depok). Jurnal Nasion al Keseh atan Lin gkungan Global Volume 1, No 2 Tahun 2020. 85-92.

Putri Nilam Sari(2016). Analisis Pengelolaan Sampah Padat Di Kecamatan Banuhampu Kabupaten Agam. Jurnal Kesehatan Masyarakat Andalas, $10(2), 157-165$.

Sulisa (2011).Tugas Akhir. Pengelolaan Sampah Berbasis Masyarakat di Wilayah Pesisir (Studi Kelurahan Pulau Penyengat). Program Studi Administrasi Publik, Fakultas Ilmu Sosial dan Ilmu Politik, Universitas Maritim Raja Ali Haji. Sugiyono, 2011:38. Metode Penelitian Kuantitatif, Kualitatif dan R \& D. Cetakan ke-14. Alfabeta. Bandung.

Prasetya Irawan, 2009:4.21. Materi Pokok Metodelogi Penelitian Administrasi; 1-12, cetakan 4. Universitas Terbuka. Jakarta.

Utami Maulida Imania dan Dian Eka A F N. (2020). Proses Pengolahan Sampah Plastik di UD Nialdho Plastik Kota Madium. Indonesian Journal of Conservation Vol. 9 No. 2: 89-95.

Mappanyompa. (2019). Penggunaan Media Tiga Dimensi Dalam Meningkatkan Hasil Belajar Atematika Siswa Kelas V MIN 2 Lombok Barat Tahun Pelajaran 2017/2018. Jurnal Prodi PGMI, 4(2). 